Where have all the women gone? On the absence of feminine agency in contemporary productions of the original Boris Godunov

Francis Maes

Ghent University (Belgium)

francis.maes@ugent.be 


\title{
Where have all the women gone? On the absence of feminine agency in contemporary productions of the original Boris Godunov
}

\begin{abstract}
The rejection of Boris Godunov for the lack of a female part is a well-known incident. In his revision, Musorgskii included the historical character of Marina Mniszech. The resulting Polish Act has been received with mixed feelings. Bias against the Polish Act is one of the reasons behind the contemporary surge of interest in the 1869 version, such as productions at the Mariiinski Theater, the Bavarian State Opera, the Royal Opera House and the Paris Opéra testify. The return to the original Boris has a side effect, however, which is precisely the one the selection committee of the Imperial Theaters warned for: it represents a world devoid of female agency. In the otherwise significant production of Ivo van Hove for Paris this omission sits uncomfortable with the social and political values that have been articulated most clearly in the \#MeToo campaign. Since Musorgskii provided an alternative, the experience of the original Boris Godunov in actual performance might stimulate a renewed interest in what is left out. Considered from the standards of the \#MeToo movement, the part of Marina Mniszech becomes significant as a reminder of the active role played by women in the historical events represented on stage. The part also resonates with the contemporary \#MeToo analysis of gender roles. Marina combines a desire for female autonomy with submission to patriarchal forces. The character could offer interesting material for a stage production that addresses the story from a modern awareness of gender roles. A comparison with Ivo van Hove's take on Schiller's Mary Stuart demonstrates that such awareness may be creatively productive.
\end{abstract}

Keywords: opera, Musorgskii, gender politics 


\section{Where have all the women gone? On the absence of feminine agency in contemporary productions of the original Boris Godunov}

At the end of the 2017-18 season visitors to the Paris Opéra were in for a special treat. This venerable institution offered them an opportunity to experience the first version of Musorgskii's Boris Godunov in a beautifully stylized production by Ivo van Hove as stage director and Vladimir Jurowski as conductor. Musorgskii finished the first version of this work in 1869 and found it rejected by the selection committee of the Imperial Theaters. Their refusal made him embark on his second version of the same opera (1872). This was produced in 1874 and became the basis for the version of Rimskii-Korsakov in which the opera became an international success, thanks to Diaghilev's spectacular production of 1908 at the Palais Garnier.

Ivo van Hove made the return to the 1869 version a condition for his involvement:

"When Stéphane Lissner offered me to stage Boris Godunov, I accepted by making clear that I wished to stage the original version, in agreement with Vladimir Jurowski."1

Productions of the 1869 version of Boris Godunov are no longer a novelty. In the late Soviet period, the original offered stage directors a way to circumvent the political correctness that Boris Godunov productions had accumulated. In the original, they could focus more on the main character's soul-searching, or emphasize the religious overtones of the drama. These were elements that were largely neutralized in official Soviet productions. However, performances of the 1869 version did not strictly adhere to the original. Producers continued to take liberties with the text. Caryl Emerson cites the Moscow Stanislavskii Theater production of 1989 as an example of the new emphasis on the religious. Several lines belonging to Pimen or the Tsarevich were given to an offstage 
children's chorus, "as if these characters exist primarily as reverberations in Tsar Boris's head".2

The Mariinskii Theater produced the 1869 Boris in 2012 in a staging by Graham Vick and with Valerii Gergiev as conductor. ${ }^{3}$ The production remained to this day in the repertoire. The earlier production of 1990 was also kept on board. That production was a revival of the legendary staging Andrei Tarkovskii originally made for the London Royal Opera House in 1983. It is not the original version of 1874 , however, but the supersaturated version with the 1869 St.-Basil's scene alongside the 1874 Kromy scene that was meant to replace it. Keeping two alternatives on the playbill is a luxury that a repertoire company like the Mariinskii can afford. Most West European theaters working in the stagione system do not have this advantage. In the stagione system, a Boris Godunov production has to stand on its own. Over the past decade, however, the original version has also been making its way through European theaters. In 2013, the Bavarian State Opera presented Calixto Bieito's reading, with Kent Nagano in the pit. ${ }^{4}$ In 2016, the Royal Opera House presented a staging by Richard Jones, as a vehicle for Bryn Terfel, with Antonio Pappano conducting. The fact that the original version has conquered institutions at the top of the operatic pecking order testifies to the fact that it is no longer downplayed as an experimental alternative, but taken as a viable text in its own right. However, for top institutions such as the Paris Opera, the choice remains a daring one. It implies a performance without some of the cherished vocal numbers that drive opera lovers to attend a Boris Godunov performance in the first place. Boris's famous soliloquy in the Kremlin scène is eliminated and replaced by an older version. The song of the hostess is missing, as well as the playful songs by the Tsarevich and his nurse and the tale of the parrot. The crucial dialogue between Boris and Shuiskii in the Kremlin scene 
has to occur in an earlier, more austere version that is less effective both musically and dramatically. There is no menacing mechanical clock to play havoc on the tsar's nerves. With the omission of the Kromy scene, there is no representation of the Russian people in revolt. The entire drama unfolds in the claustrophobic milieu of the Kremlin, with only one aside to an inn at the Lithuanian border. Another consequence is the reduction of the parts of most characters to a bare minimum. The hostess, the Tsarevna, and the Tsarevich do not have much to sing other than short replies. Contemporary singers seem to resign themselves to these austere conditions, which offer them little chance to shine in their own right. Thanks to the perceptive stage direction of Ivo van Hove, the inspired set and lightning of Jan Versweyveld, the video projections of Tal Yarden, and the dedicated conducting of Vladimir Jurowski, the Paris Boris Godunov fulfilled all its promises to become a landmark in the recent reception of Musorgskii's masterpiece.

Respect for the opera in its original form does not mean that producers accept the limitations of the text at face value. For instance, Valerii Gergiev and Graham Vick reinstated the song of the hostess in the inn scene. Calixto Bieito did stick to the text, but added extra plot turns. He changed the Tsarevich into Boris's daughter. He has the Holy Fool killed on the command of Shuiskii at the end of St.-Basil's scene. In order to turn the drama into a confrontation between the tsar and the Russian people he employs massive armed forces to contain a protesting crowd. Bieito has the nurse, Kseniia and the “Tsarevich/Tsarevna” killed at the moment of Boris’s death. Ivo van Hove sees the opposition between power and people as the core of the drama: “In Musorgskii's opera, Boris has a vision. He proposes concrete solutions. But he commits an error, as he believes that he can rule from his office at the Kremlin. This explains his break with the people." 5 
To make this interpretation work, Van Hove had to add an extra dimension to the text. By using magnificent video footage by Tal Yarden the production breaks down the Kremlin walls and leads the viewer to wide vistas of the Russian landscape. The visual content of the production liberates the drama from its closeted form. It adds tension between a palace drama and a view of Russia at large, which is not literally present in the text.

Ivo van Hove's comments in the Paris stage bill indicate an additional reason for his choice:

"It has no Polish Act, no ballet, no love story. The secondary parts are reduced to a few scattered lines. Through its concentration on the rise and fall of tsar Boris, this version is more Shakespearean."6

Put this way, his choice appears to some extent motivated by a negative argument: the avoidance of the Polish Act, which Musorgskii composed in a more consciously operatic manner. Many music lovers regret the composer's flirting with ballet music and a conventional love duet. Ivo van Hove echoes a long-standing bias against the second version of 1872, one that was already articulated by contemporaries like Vladimir Stasov and César Cui: ${ }^{7}$

"I believe that this is the version Musorgskii wanted. It appears to me more personal, more dramatic and more political." 8

This statement repeats the widely held assumption that Musorgskii altered the work out of expediency. To secure performance, he would have been ready to sacrifice his originality on the altar of convention. Stage directors have sometimes simply cut the 
Polish act from the otherwise complete supersaturated version, defending this measure as a return to Musorgskii's original intentions. ${ }^{9}$ Today, they seem to prefer to avoid it altogether by sticking to the 1869 version, even if it means the sacrifice of great music. Recent scholarship has dealt with this bias against the Polish Act and proposed a reappraisal. For Richard Taruskin, the composition of the Polish Act helped Musorgskii to transcend the strict text setting and radical naturalism of the pioneering years of Russian opera. Although based on Pushkin's Polish scenes - the discarded boudoir scene and the scene at the Fountain - Musorgskii wrote his own dialogues. In probing a new lyrical manner, the experience with the Polish Act paid off in his revision of the Russian scenes as well. A further measure was the clarification of the role of the Pretender's leitmotif, since in the original it could apply both to the murdered Tsarevich and to the Pretender. The revision resulted in an elevation of tone that made the music more appropriate for tragedy. 10

Caryl Emerson notes the melodramatic turn in Musorgskii's concept of the Polish scenes, but praises his ability to balance the love intrigue between the Pretender and the Polish noblewoman Marina Mniszech with the political cunning of the court Jesuit Rangoni. The latter serves as a counter-balance to the orthodox monk Pimen. The contrast between the two clerical characters points to the spiritual divide between the Catholic West and Orthodox Russia. ${ }^{11}$

Emily Frey notes that the Polish Act has its function in the clarification of the character of the Pretender. In the original version, the Pretender was a man without a cause. Besides his own passion and ambition, he lacked a political motive to challenge Boris. Set against the wave of terrorist attacks during Musorgskii's lifetime, the two versions represent different approaches to the understanding of the psychology of the terrorist/ pretender. ${ }^{12}$ 
Marina Frolova-Walker views the Polish Act as an exercise in local color:

"The most striking example, of course, is the Polish act, which many Boris adepts find regrettable, reproaching Musorgskii for selling out, for 'lapsing' into a universal style. But I would suggest this is not quite the case: rather, the Polish act is justifiably more conventional simply because the action is taking place in Poland-in the West, as far as Russians were concerned."13

Along the same lines, she argues that the style of the Russian scenes is also precisely that: an application of local color. The Russian style did not become a default style that signified Russianness at every level: "The universal and the Russian did not switch places. The Russian remained a color and had to be used accordingly."14

\section{No women in politics}

However the Polish Act may be judged, a return to the original Boris has had the unfortunate side effect the selection committee of the Imperial Theaters warned for: the lack of a female part and, in consequence the omission of female agency from the drama altogether. It makes performances sit uncomfortably with contemporary societal values. The 1869 version, as the Van Hove production testifies, represents a world devoid of feminine agency. It depicts a political milieu in which women do not seem to exist. Not merely are they silenced or rendered impotent to intervene in political matters, they are simply not there, with the exception of tiny stretches of dialogue or ritualized lamenting. Tsar Boris, tellingly, sends his daughter away from his war room at the Kremlin. The Tsarevich is allowed to stay and learn the art of statecraft, until matters become too delicate for his young ears. 
It is old news that female characters in opera suffer from patriarchal oppression. Since Catherine Clément's seminal publication Opera, or the Undoing of Women, ${ }^{15}$ the patriarchal structures of most operatic plots have become central to the critical debate of the genre. Even more disturbing, however, is the obliteration of feminine agency as such. In times of renewed debate on women's rights, spurred by the \#MeToo campaign, a theatrical representation of a world devoid of women as acting subjects must seem strange and incompatible with modern values. In his Munich production, Calixto Bieito circumvented the problem by turning the Tsarevich into a girl. At the conclusion of the St. Basil's scene, he has a girl kill the Holy Fool. Her action is not voluntary, however, but dictated by Shuïskii. The boyar has noticed the hostility the girl displayed toward the Holy Fool and uses it to his own ends.

Ivo van Hove sticks to the text as it stands and treats the female characters as decorative (Kseniia) or instrumental to male intrigues (the hostess). Marina Frolova-Walker advised caution in equating the Russian folk style, in which Kseniia sings, with a reduction of the role of women to the decorative:

"Without claiming that the result is to relegate the women to a decorative background level, I would suggest that women were seen as lending themselves more easily to ritualized expression as opposed to the individualized expression of the male protagonists." 16

In the portrayal of Kseniia, however, this is precisely what happens. She has no voice of her own, as compared to the Tsarevich.

Graham Vick's portrayal of the hostess is drawn along the most blatantly sexist lines. The inn she runs is a whorehouse. While singing the song of the drake, she inspects and selects girls for her establishment. The representation of women in Vick's production 
follows the most stubborn sexist dualism of woman as either whore or virginal bride (the Tsarevna dressed in her white wedding dress).

The representation of a world without feminine agency on stage discards half a century of feminist critique against the power of art to justify or render acceptable a vision on the world that dehumanizes women. Today, the \#MeToo campaign exposes systematic violence against women. The campaign focuses on sexual exploitation in the first place, but has also laid bare some of the power structures that lie at its basis. The campaign differs from previous feminist activism in its disclosure that even women with significant careers, at the height of fame and influence, may have been subjected to abuse. In the West, journalistic investigations of Jodi Kantor and Megan Twohey contributed to bringing to light the power structures behind the secrecy that enveloped deeds of sexual abuse. ${ }^{17}$ As Susan Faludi comments, their work offers "a solvent for the structures that enforced that secrecy".18 In Russia, the movement took off somewhat later. Commentators agree that protest against sexual abuse is more difficult there, because of official opposition against feminist critique and a culture of victim blaming that is still strongly in place. Female twitter users, however, have started their own movement to share their stories under the hash tag \#Mne nuzhna glasnost' (I Need Openness, or I Need Public Attention). ${ }^{19}$

The impact the movement may have on Russian theatre and opera is beyond the scope of this article, besides the fact that questions of gender in Russian opera still have to be fully addressed. The most debated case up to the present is the character of Katerina Izmailova in Shostakovich's The Lady Macbeth of Mtsensk. Since Richard Taruskin's harsh criticism on the opera as a profoundly inhuman work, ${ }^{20}$ the discussion on the nature of 
Katerina's actions is still going strong. ${ }^{21}$ For Boris Godunov, the question is different, centering in the first place on the place of women in the historical story the opera represents. Did women have a role to play within the power structures of their time? The addition of the character of Marina Mniszech in the revised version demonstrates that women's role was anything but passive. The actual historical character is, in fact, a case in point. A second question is the way in which she is represented in the opera. Although largely an episodic character in the course of the drama, Marina's actions may shine a new light against the background of the contemporary \#MeToo concerns.

\section{Authenticity and modernity}

The Paris production demonstrates irony on two points. The first irony resides in the fact that modern aesthetics do not necessarily correspond to modern societal values. The appeal of the 1869 version for modern stage directors is understandable. The centrality of the character of Boris makes for a concentrated drama on the tragic consequences of moral transgression. Ivo van Hove feels liberated from operatic trappings. Nevertheless, scholarship has demonstrated that the modern traits we value today were received in Musorgskii's time as not entirely fitting for the lofty subject. Richard Taruskin concludes that we should take Musorgskii's work on Boris Godunov as a work in progress. He sees in the revised Boris the real masterpiece and in the earlier version "a document of a particular moment in the history of Russian opera and of its composer's creative development".22 The reaction of his peer group of aristocratic connoisseurs, who confessed confusion about the opera's genre, incited Musorgskii to revise: 
“Musorgsky's first impulse to revise came in the form of a reconsideration of his operatic technique with an eye toward clarifying the 'genre' of the opera - that is, toward making decisive the contrast between what was 'bouffe' and what was not, and generally toward elevating the tone of the opera, as Prince Odoyevsky had said of $A$ Life for the Tsar so many years before, 'to the level of tragedy'”23

As a consequence, the quest for authenticity projected in the choice of the original version comes down, ultimately, to a projection of modern standards on a nineteenthcentury text.

All aesthetic choices of the staging confirm the impression of modernity, such as Ivo van Hove's characteristic way of universalizing historical drama through the use of modern costumes, ascetic and largely abstract sets, the role of video projection to represent the wider world and the use of contemporary gestural language.

All these modern trappings, however, do not necessarily ensure the representation of modern societal or political concerns. It has already been observed that modern aesthetics do not automatically guarantee contemporary views on ethical issues. Simone de Beauvoir has already made this point in Le deuxième sexe, when discussing modernist authors like Henry de Montherlant, D.H. Lawrence, Paul Claudel and André Breton. An author who managed to treat women as persons of flesh and blood was not a modernist, but the nineteenth-century writer Stendhal:

"When I leave the contemporary age and return now to Stendhal, it is because after quitting these carnivals where Woman disguises herself as a shrew, a nymph, the morning star, or as a siren, it is comforting to meet a man who lives among women of flesh and blood". ${ }^{24}$ 
Susan McClary made a comparable point by reading Peter Brook's modernization of Carmen in La tragédie de Carmen (1981) as a reactionary act that cleansed the drama of the liberal touches in Bizet's original, even when they remained embedded within patriarchal structures: "The interpretation is formalistic, ahistorical, apparently apolitical, as are most reflections on 'fate' and 'the human condition'... But in the 1990s, Brook's portrait of Carmen and her demise counts not simply as a retreat, but as a reaction against the advances won by women in the last two decades. The rigid law of Brook's triangulations - the tarot cards he metes out to Carmen - will admit of no agency, no license."25

The second irony is possibly even sharper: Musorgskii had corrected the omission himself. He had added a female character to the drama, a task he undertook, as witnesses have observed, with enthusiasm. ${ }^{26}$

The advice to provide a female part may have been an aesthetic one in the first place. Opera thrives on the fascination that the female voice and its sublimated erotic power incite. Whatever the reasons, the result was beneficial. The second version of Boris Godunov represents a world in which women do take part in political intrigue. Although the actions of the Polish Marina Mniszech are framed as a threat to the survival of the Russian state, the character adds a convincing case of female agency to the drama. The experience in the theater of a Boris Godunov without women may cause us to look at the character of Marina Mniszech with new eyes. In the scholarly literature, she does not receive much attention. Assessments of the value of the Polish Act usually concentrate on the role of the Jesuit courtier Rangoni or the impact of the Pretender's love interest on the development of his character. 
What makes Van Hove's choice for a drama without feminine agency particularly problematic is his insistence on the political nature of the 1869 version. Van Hove defines the political specifically in the conflict between good intentions and the impotence to realize them. It is the ancient Aristotelian type of the tragic character that is neither good nor bad and brings about his fall as a consequence of a specific mistake. Such a vision on the political recurs in some of Van Hove's greatest productions, like the Roman Tragedies, Kings of War or even in his portrayal of Creon in Antigone. It was also the impulse behind his treatment of the character of Wotan in his Ring Cycle for the Flemish Opera. ${ }^{27}$ As a definition of the political in drama, however, it remains one-sided in its focus on the character flaws of the ruler. Applied to Russian political history it is decidedly reductionist. Moreover, it eschews a reference to more contemporary political concerns, in which gender politics are largely present. This is not to argue that it should be dictated that theater should address contemporary concerns in its reading of a classic, but Boris Godunov is precisely one of those exceptional works that have proven their relevance to ever changing political contexts. If the theater itself does not offer that translation, critical analysis can step in to complement what the stage has left unsaid. Van Hove's production may serve as an incitement to revise the part of Marina Mniszech in the light of the contemporary \#MeToo campaign. Set against this background, the character may be viewed as a precious gift for a sensible stage director.

In search of the vox feminae

Were Russian politics at the dawn of the modern era an exclusively male business? The available historical literature suggests otherwise. After all, Russian tsarist history 
includes some imposing female characters. Catherine the Great ranks with the British queens Elizabeth I, and Elizabeth II for that matter, and Victoria among the most successful monarchs of all time. With respect to feminine agency, Musorgskii's 1869 Boris is not entirely faithful to history.

The period in Russian history that the opera deals with is called the Time of Troubles. This was decidedly a time when powerful women influenced the course of events. Marina Mniszech was one of them, as was Irina (Tsar Fedor's wife and Boris's sister) and Mariia Nagaia (the mother of the child Dmitrii). In his account of the Time of Troubles, Isaiah Gruber argues that the question of non-hereditary succession that triggered the events was solved through the elaboration of an ideology based on three deciding factors: Vox Dei, Vox Populi and Vox Feminae: the voice of God, the voice of the people, and the voice of woman. In the last category, Gruber refers to the role women played in the transmittal of power to an un-hereditary ruler, thereby influencing the course of events in a decisive way. ${ }^{28}$

The first of them was Irina Godunova, the widow of Tsar Fedor and sister of the regent Boris Godunov. While some historians have concluded that Irina could have made a claim to rule herself, Gruber would not take his argument this far. While there had been precedents of female rulers in Kievan Rus', this exact situation had not yet arisen previously in Muscovy. Nevertheless, the status of Tsaritsa Irina contributed to an increase of the degree to which women contributed to the decision-making process: "Vox feminae, the authorizing voice of a royal woman, represented a significant innovation in official politics when it appeared in the Time of Troubles. Although Irina notably did not become the principal ruler of Russia, her status did provide the main justification for Boris's accession in early 1598. This legitimizing role - shared by several other women 
of the period - may have been a transitional stage in preparing the way for later female rulers of Russia." 29

The historical reality portrayed in Boris Godunov continues to puzzle historians. It dramatizes a period in the seventeenth-century historical crisis that was born out of the efforts to centralize the country. This crisis would eventually lead to the political consolidation of the Russian state under the Romanov dynasty. The story of Boris Godunov stands at the beginning of the so-called Smuta, or Time of Troubles (1598-1613). Recent scholarship defines the Smuta as Russia's first civil war. ${ }^{30}$ Its origins should not be attributed to the actions of tsar Boris alone, nor of his opponent, known as the first False Dmitrii. The cause resided in a combination of factors. The Smuta represents the first crisis of the tsarist autocracy after the unification of Russia under the Grand-Princes of Moscow Ivan III, Vasilii III and Ivan IV, the first ruler to adopt the title of tsar.

The first stage of the crisis was caused by the extinction of the Riurikid dynasty that had ruled over Russia since the ninth century. The Moscow branch was called the Daniilovich dynasty. They were descendants of Aleksandr Nevskii's youngest son Daniil. Fedor I, the feeble-minded son of Ivan the Terrible, died without an heir. At that time, the Russian state did not possess a legal solution concerning succession in such a case. The extinction of the ruling dynasty was a blow to the myth of their divine ordination. In the power struggle that ensued, Boris Godunov appeared victorious. He especially had to outsmart the claims of the Romanovs, who could boast of closer blood ties to the deceased dynasty through Anastasia Romanova, the first wife of Ivan IV.

The Orthodox Church created a new ideology on which succession could be based: 
"In 1598 Patriarch Iyov and other top Muscovite ideologues acted to forestall the crisis of legitimacy that could have erupted at the times. Because the new tsar lacked hereditary legitimacy, they created an alternate paradigm for justifying the rule of an Orthodox sovereign. While emphasizing divine providence and the authority of the Church, the new approach replaced traditional dynastic bequest with notions such as vox populi (the voice of the people) and vox feminae (the voice of a woman). In the Muscovite context this model was quite novel, and did not emerge overnight." 31

In the opera, the accession of Boris Godunov to the throne was based on his election by the zemskii sobor, or "assembly of the land." Part of the machination during the process consisted of forcing ordinary men and women to beseech Boris to accept the throne, which is the scene on which the opera opens. The patriarch sanctioned the accession in a letter that tells of a large procession of churchmen, boyars and common Orthodox Christians, who had assembled with icons and crosses at the Novodevichii Monastery to plead to Tsaritsa Irina to bestow the crown on Boris. ${ }^{32}$ This incident is also echoed in the opera in the chorus of the itinerant blind pilgrims.

The story as told in the opera derives in its broad outlines from The History of the Russian State (1816-1826) by Nikolai Karamzin. Since he was the house historian of the Romanovs, Karamzin's interpretation of the Time of Troubles was monarchist and providential. The task he set himself has been compared to Shakespeare's in his dealing with historical English kings: "both had to refashion disparate chronicle accounts into the coherent prehistory of the current ruling house without totally sacrificing accuracy and drama." 33 Karamzin declared Boris responsible for the murder of the child Dmitrii, the last son of Ivan the Terrible. In this interpretation, the murder was the means by which Boris paved his way to the throne. Karamzin attributed the unfortunate state of 
Russia during Boris's reign - when it had to endure a devastating famine caused by sudden climate change - to a divine retribution of his sinful act of usurpation. Karamzin's version is a typical victor's tale. By accusing Boris of the murder, the Romanovs destroyed all the legitimacy their former rival may have had.

Modern historians no longer support Karamzin's argument. Boris committed many atrocities against his rivals and this one would hardly have made a difference, Dmitrii's death would not have benefitted Boris at a time when tsar Fedor could still have produced an heir.

The child Dmitrii would have been forgotten, if his name had not turned up again during the disastrous years of famine. The unfortunate circumstances spread a general mistrust of Boris's rule and a feeling that God had deserted Russia. In this context, a pretender stood up and called himself Dmitrii Ivanovich. Some claimed that he was resurrected, others that had been miraculously spared from death, while another child had been killed in his place.

The main way to discredit the claims of this mysterious Dmitrii was to prove that he was a fraud. The most influential story was his identification as Grigorii Otrepev, a Muscovite monk with heretical views. This is the man who acts as the Pretender in Musorgskii's opera. The fabrication of the Grigorii story was strategic and did not have serious claims to authenticity. Modern scholarship tries to solve the riddle of the False Dmitrii's identity by surmising that the man must have really believed that he was the son of Ivan IV. Otherwise, his successful campaign would be hard to explain. This belief may have been instilled in him by people who had an interest in overthrowing Boris's power, the Nagoi clan in the first place, but a case has also been made for the Romanovs. The portrayal of Dmitrii in recent scholarship focuses on his belief in his mission. 
When Aleksander Pushkin transposed these events into drama, he made no effort to solve the riddle of the False Dmitrii's identity. Instead, he elaborated precisely on the role of the unknown as an engine behind historical developments. Pushkin thwarted the expectation that he would go further than Karamzin in revealing the truth behind the official history:

"What Pushkin served up to his readers conformed neither to the climactic five-act structure of a tragedy nor to the revelational mission of Romantic historiography."34

Pushkin depicts the Pretender as a chameleon, who changes identities and objectives according to other people's expectations. He is no one, but can be anyone, fully aware of the motives that others project onto him. His great exchange with Marina Mniszech shows him at the limits of his power of self-invention. In a daring reversal of the question treated by Shakespeare in Romeo and Juliet on the relationship between name and identity, Marina concedes that she could not love him under any other name than Dmitrii. By revealing that he is not the person he claimed to be, he nearly loses all. He only regains Marina's confidence by demonstrating fully his powers of deception. If she wants him to be Dmitrii, he shall become him.

\section{Marina Mniszech as history and enigma}

Marina Mniszech is the only woman in this historical struggle to receive a place in the opera. The others, Fedor's widow Irina Godunova and Boris's wife are entirely absent. Recent scholarship has reassessed their contributions. Isaiah Gruber makes the point that women did receive an authoritative voice in the political process. Before the Time of 
Troubles, succession depended on the act of bestowal, or "blessing" of a successor by the male ruler. To legitimize the succession by the non-hereditary Boris Godunov, the Orthodox Church accepted his blessing by Tsaritsa Irina as a justification of equal weight.

This precedent led to a new ideological foundation for the succession of power. When tsar Boris died in 1605 , the legitimacy of his son Fedor II did not rest so much on his filial ties with the deceased ruler, but on the blessing administered by his mother Tsaritsa Mariia. It is significant that the False Dmitrii had both Fedor and his mother killed, to remove Tsaritsa Mariia as a political factor.

This tale continues accordingly. False Dmitrii's ascendancy depended, in his turn, on the recognition and blessing by his assumed mother Mariia Nagaia. After Dmitrii's death, the Second False Dmitrii's claim rested on Marina Mniszech's recognition of him as her husband. The Time of Troubles would come to an end with the ascendancy of Mikhail I Romanov, whose legitimacy was founded on the same cluster of criteria as established at the time of Boris's coronation. The woman's voice in this case was his mother's, Marfa (born as Kseniia) Romanova.

This pattern would be repeated later in Russian history, most conspicuously when Peter the Great would come to power. At that time, two powerful women would clash over the succession, Peter's mother and the notorious Tsarevna Sophia. In the eighteenth-century, the vox feminae as established in the Time of Troubles would pave the way for the female tsars of the Enlightenment.

The ideological development during the Time of Troubles did not yet depend on enlightened values, but mainly on the status of the Mother of God and the devotion to female saints: “Great devotion to the 'heavenly tsaritsa' and faith in her powers were widespread during the sixteenth and seventeenth centuries in Muscovy; they seem to 
have contributed to the acceptability and appeal of assigning legitimizing power to an earthly tsaritsa."35

Musorgskii's opera obliterates the role of women from the process entirely, except for the one that historians could not possibly avoid: Marina Mniszech. She was a daughter of Jerzy Mniszech, a Polish magnate who assisted Dmitrii in the military preparations of his campaign. Mniszech promised him Marina's hand. The marriage would eventually take place after Dmitrii's ascendancy to the Russian throne. His relationship with the Catholic Marina gave much food for speculation. In the ideology of the Romanovs, Marina served as a pawn in a Jesuit plot to convert Russia to Catholicism. There is some evidence of Catholic meddling in Dmitrii's campaign. Upon his coming to power, however, the historical Dmitrii acted in full transparency with the Russian orthodox authorities. He posed no threat to the orthodoxy of the Russian people and did not particularly favor Catholicism over other religions. Marina was crowned in Moscow after Dmitrii's installation. For a tsar's consort, this was an unusual procedure. After the assassination of her husband on 16 May 1606, she was held captive and sent back to Poland. In order to regain her throne, she married another impostor, the Second False Dmitrii, claiming that she recognized him as her husband, who had once more miraculously been saved from death. False Dmitrii II was killed in 1610. In 1611, Marina gave birth to a son, Ivan, whom she claimed was Dmitrii's son and his legal successor. The plan did not work and Marina had to flee to Astrakhan. With the election of Mikhail Romanov in 1613, her ambitions reached their end. On 24 December 1614, she died in prison at the Kremlin of Kolomna, after seeing her son Ivan executed. She was twenty-six at the time of her death. 
Given the drama of her life, historians could not confine her to a footnote. Some confessed outrage at her exceptional will, but most of them did not treat Marina as a woman with personal agency. Aleksei Yudin analyzed the role that several generations of Russian historians have accorded her. ${ }^{36}$ The eighteenth-century historian Vasilii Tatishchev interprets her role through a conventional patriarchal perspective, in which women were not credited with personal ambition and initiative. Tatishchev understands Marina as a passive instrument of the ambition of her father. All the signs of autonomous political action on her part - like her insistence on a personal coronation ceremony - are labeled as unfeminine in the patriarchal society of Muscovy. In the account of Mikhail Shcherbatov, Marina acts more autonomously. She does not merely play the role her father entrusted to her, but acts from a pernicious personal ambition. In his characterization of that ambition, Shcherbatov follows the traditional stereotypes that sharply distinguish the proud, ambitious Poles from the humble, God-fearing Russians.

Nikolai Karamzin devoted more attention to Marina's character. He saw the girl's innocence corrupted by the temptation of ambition. The evolution from innocent maiden to ambitious impostor follows the orthodox views on the devastating effect of temptations on the soul.

The History of the Time of Troubles by Dmitrii Buturlin is characteristic of the ideological context during the rule of Tsar Nicholas I. Buturlin attributed Marina's ambition as the source of her evil actions, but unlike Karamzin he did not grant Marina a psychological development from innocent girl to political strategist. Buturlin portrays her as evil from the start. The Polish threat received much attention and reflected the then contemporary fear of the rebellious Poles within the borders of the tsarist state under Nicholas I. Buturlin's account follows the official narrative about Russian history as dominated by a 
continuous struggle between the spiritually superior Orthodox Russians and proud and ambitious aggressors, like the Poles, the German Knights, the Mongols, or the Jesuits.

The nineteenth-century historian Sergei Solov'ev attributed Marina's independence to her Polish character. Polish women were considered strong-minded and ambitious, in contrast to the modesty of their Russian counterparts.

Nikolai Kostomarov, the populist historian whose influence on Musorgskii's second version of the opera is well documented, ${ }^{37}$ gives much attention to the Jesuit plot. The fact that a woman could exercise such an influence on Russian history could hardly be explained on the basis of her personal agency alone. According to Kostomarov, it was due to the Jesuits' ambition to bring the Russian Church under the authority of Rome. Kostomarov considered this Jesuit conspiracy as the primary explanation of Dmitrii's campaign. He saw Catholicism as un-Russian and contrary to the beliefs of the Russian people. Musorgskii demonstrated this idea most clearly in his Kromy Scene, where the presence of two Jesuits provokes a violent reaction.

Kostomarov describes Marina as beautiful but strong-willed and idle. Musorgskii developed his portrayal on the basis of the dualism in Kostomarov's appraisal: a character with a will of her own, but also a puppet in a sinister plot designed by her father and the Jesuits.

So it was not Marina, but only the woman in me that attracted you?

In Pushkin's play, no realm is immune for political intrigue. As Monika Greenleaf puts it: "there is no oasis in the world of Boris Godunov for non 'princely' values." 38 Musorgskii did not take Pushkin's text literally. His departure from his strict opera dialogué mode has been commented upon as an indication of his developing 
understanding of opera as a dramatic system with its own laws. ${ }^{39}$ At first glance, he seemed to introduce an oasis of charm and innocence at the beginning of the Polish Act. Pushkin discarded a preparatory scene in which Marina converses with her chambermaid during her toilette. Musorgskii did not only reinstate a preparatory scene, but extended it into a decorative tableau with pastoral overtones. Ladies-in-waiting sing the praises of Marina's beauty and her prospects of attracting the most worthy suitors. In the course of the drama, the scene functions as an intermezzo, as the oasis that Pushkin eschews. However, it has its function in delineating the character of Marina. The imagery used by the ladies-in-waiting refers to the vocabulary of courtly love. It clearly defines the role Marina is expected to play. The princess is immured, not only in her feminine quarters, but also in her prescribed role as an object of male courtship. Marina's boudoir scene highlights her individual will, by contrasting it sharply with her prescribed role. She refuses to be praised along gendered lines. She identifies with role models, such as the courageous maidens that took part in Poland's heroic struggles. The scene indicates that her will is not content with the limitations imposed on her. In the aria that follows, she expresses her expectations in a fierce mazurka rhythm that characterizes both her Polish identity and the force of her ambition. At the end of the aria, Marina bursts into laughter, realizing suddenly how far away her imagination has carried her.

Her capricious laughter serves as a contrast for the sudden menacing entry of Rangoni. He is portrayed according to the stereotypes that surround the Jesuit order ever since Blaise Pascal's scathing review of their intellectual and political manners in his Provincial Letters. In the seventeenth century, Jesuits met with mistrust of their actual political engagement on the suspicion of some deep strategy behind their actions and teachings. ${ }^{40}$ Especially by espousing Machiavelli's concept of the Reason of State, Jesuits 
were considered to be his devoted followers: "By the early seventeenth century, the Machiavellian Jesuit was already a cliché among the Society's host of enemies."41

Rangoni's request to Marina is a classic example of the alleged double standard in Jesuit ethics. He asks her to seduce the Pretender with her feminine charm, even if it would lead her to sin. Her erotic transgressions would be pardoned if they serve the greater good. She should secure the vow of the Pretender to convert Russia to Catholicism. Reasons of state have to supersede personal ethics.

In the dramaturgical structure of the 1872 version, the character of Rangoni serves as a counterpart to the portrayal of Orthodox values in the cell scene at the Chudov Monastery. Knowledgeable of the ways of the powerful, Pimen came to acknowledge the ideal of the Christian ruler in the feeble-minded but pious tsar Fedor, and ascribed the prosperity of the country to God's approval of its God-fearing leader. Rangoni, on his part, seeks the company of scheming courtiers, and ultimately of an impostor. In his musical portrait, the dualism between his own apocalyptic convictions and his approval of insincerity and deceit in the service of the greater good is represented in the contrast between the binary rhythm that stands for his inner conviction and the ostentatious use of triplets that characterize his manipulative voice. He uses this idiom to influence Marina and to address the Pretender.

Most interestingly from the \#MeToo perspective is his strategy to gain control over Marina's soul. When he asks her to charm the Pretender with her beauty, he only requests something of her that she was already prepared to do on her own initiative. What troubles her, however, is Rangoni's demand that she should do so in the service of a goal that goes beyond her personal ambition. She cannot accept that another's will 
would supplant her own. Rangoni resorts to violence when he sees that his plan has failed. He knows her weak spot and exploits it mercilessly. He threatens her with eternal damnation. Rangoni knows that her haughty behavior hides devotion and fear for sin.

According to \#MeToo standards, Rangoni's action is a violent assault on a woman's autonomy. He is capable of breaking her will and of supplanting it with his own through the supreme patriarchal power he exercises over her. Rangoni's hold on Marina is also a violent seizure on female sexuality. His request to use her sexuality in service to his goals turns it into an instrument in the hands of others.

Marina's portrait comes alive because of the ambiguity it entails. On the one hand, she wants to break free from the confinements of her feminine world, on the other she sacrifices her free will to patriarchal command.

The ambiguity of the operatic Marina contrasts with the portrait in Pushkin's play. His Marina seeks to achieve her ambitions without the slightest hesitation. In the language she uses, she breaks free from all the codes that entrap women in their prescribed roles. She does not want to become Dmitrii's trophy wife, but an equal partner in his political strategy:

"Not as a slave to male whims,

Not as your mistress who has nothing to say,

But as a wife and comrade, who is worthy of thee." 42

The operatic Marina is less straightforward in the expression of her ambition. The Dmitrii she encounters is already in love with her. Pushkin's Pretender remains tactical. Musorgskii's Pretender declares his love directly and passionately. Marina makes fun of 
him, teasing him about his romantic ideal of pure love and an anonymous life in a humble cottage - a line that comes from Pushkin, but that Musorgskii transferred from the Pretender to Marina. In this way, she makes it fully clear that she understands the scope of his desire. She goes on to reproach him for only desiring the woman in her and not herself as a person. When he begins to beg her, she scorns him for his irrational behavior. Pushkin's Pretender regains control over the situation as soon as he realizes that he is on the brink of losing a tactical game. Musorgskii's Dmitrii takes control of himself out of wounded pride. Now it is his turn to threaten Marina with scorn. He will humiliate her when he becomes tsar. At this moment, it is up to Marina to give in to his passion. She is ready to submit herself to his desire. The dialogue and the music take an amorous turn that is absent in Pushkin. Although it makes the dialogue more conventionally operatic, it serves to complicate the relationship between Marina and the Pretender. Politics mingle with personal feelings in a more subtle way. Once the couple gives free reign to their amorous feelings, Musorgskii only needs a few comments from Rangoni to remind us that politics are not far away. When the triplets, once imposed by Rangoni, give way to the pastoral measure of $9 / 8$, it becomes clear that his will pulls the strings in the oasis that is setting in. Rangoni even complements the pastoral duet with subtle touches of a siciliano when he observes the couple's simplicity and tenderness.

Van Hove' theater and Female agency: Antigone and Mary Stuart

The absence of female agency in his Boris Godunov production presents an extreme case in Ivo van Hove's theatre. Omission of female agency is not the rule in his work. A fine characterization of a great female politician is his take on Fricka in Wagner's Ring. Fricka 
is represented as a woman who does not take no for an answer, who sees through Wotan's attempts at self-justification and is unimpressed by his unrealistic goals. ${ }^{43}$ Complicated women have regularly occurred in Van Hove's earlier work. ${ }^{44}$ Marina Mniszech could have joined their ranks. However, Van Hove's take on female agency within power relations is not always clear-cut. Two recent productions may put this in perspective: Antigone and Mary Stuart.

Antigone (2015) was conceived as a vehicle for the French film actress Juliette Binoche. The casting of a great movie star in a most iconic part raised high expectations. The mixed reviews indicate that those expectations were not entirely met. Star envy may have been one of the unspoken reasons, but also perhaps the fact that Binoche did not surpass the rest of the cast. She did not appear to be a Sarah Bernhardt who dwarfs all other performers. To strive for an ensemble-like result could have been a conscious choice. However, Binoche's performance contributed much to the general feel on the production. More than one reviewer confessed to have been unmoved: "Although tragedy after tragedy unfolds before your eyes, you are left completely cold." 45 Another reviewer puts it: "What becomes clear quickly is that celebrity status is not the same as tragic stature. Binoche's shrill Antigone is a diminished figure, more hysteric than heroine there is much hoarse screeching and high-pitched shouting and only intermittent pathos." 46

The reduction of high pathos may have been the intention of the director. He conceded that he wanted to humanize Greek tragedy. ${ }^{47}$ Humanization included the reduction of the larger than life status of tragic heroes and a focus on human relationships rather than on the grand ethical knot around which Sophokles's tragedy evolves: 
"With the (rather American) hyper-organic acting on the one hand, and the (rather European) hyper-realistic unspecific set on the other, van Hove's Antigone reveals the tragedy of an unspectacular and human failure of responsibility toward the Other, a call to humbleness, which actually approaches closer to our lives than any of the recent sensationalistic news-story scandals. This might be exactly what creates unease: that he confronts us with ourselves and the fact that the most terrible conflicts are in fact the trivial ones that we confront day-to-day." 48

This is one way of making sense of Van Hove's take on Antigone. Put like this, the production amounted to a reduction of tragedy as a representation of conflicting agencies. Whereas Creon is represented as a man of considerable power, Antigone does not seem equally capable of confronting his will. Binoche's Antigone reveals more resignation and grief than a command of her agency. Antigone loses in the conflict, but she also fails to win the quest for ethical supremacy.

A drama that puts female agency center stage in political relationships is Schiller's Mary Stuart. Ivo van Hove presented his interpretation of Schiller's classic in 2014 in a production of Toneelgroep Amsterdam - now Internationaal Theater Amsterdam. The tragedy of the rivaling queens, Mary Stuart and Elizabeth I, offers a compelling meditation on female agency and power at the beginning of modern times. Schiller famously had the two women confront each other in a meeting that in reality never took place.

Ivo van Hove focused his interpretation on the conflict in Elizabeth's mind between personal feeling and the need for harsh political decisions. This dilemma forms a severe 
test of statesmanship. Van Hove painted both women as characters that were aware of their role in history. The production ends on the ritualized image of Elizabeth I as she is known in her regal status. The ending suggests that the success of Elizabeth's glorious reign was not so much the result of her own intelligence and the quality of her decision making, but of her ability to act according to the will of the nation.

The ending extends the image of Elizabeth's solitude at the end of Schiller's text. All her loyal advisors leave her. The queen's solitude is, however, not only the result of the dilemmas involved in ruling. It is as much the outcome of her inner conflict.

The drama paints the process in which Elizabeth loses her inner self. Schiller represents her as a person who is divided between two characters. As a woman in power, she follows the dictate of her people and her political advisors to condemn Mary Stuart to death. As a person, she is not prepared to act in the prescribed way. She overcomes her burden in a famous scene, in which she does sign the death warrant, but leaves it to her minister to decide about the consequences of her signature. By stating that words do not kill, she leaves the burden of the decision in his hands, while she knows all too well what the result will be. This disturbing act of diverting responsibility leads to a harsh punishment for the minister once the death sentence has been carried out.

In Van Hove's interpretation, the theme of political agency stays within the limits of expectations regarding gender roles. The impulse to place human feeling above political reasoning is still represented as a feminine prerogative. However, Van Hove's production offers a striking and beautiful example of gender reversal, precisely in a situation where we would not expect it. Before her execution, the Catholic Mary Stuart has been denied the comfort of a confession to a priest of her own church. In Schiller's play, her chamberlain Melville takes up the role. Schiller refers to Christ's message that he would be present where people gather in his name. According to these words, a confession 
between like-minded Christians would be valid in itself, even without the absolution of an ordained priest. In the play, however, Schiller does not go so far. Melville reveals himself as a secretly ordained priest, who has managed to keep his status hidden.

Ivo van Hove changes Schiller's text at this point. He makes Hanna Kennedy, Mary's former nurse and life companion, perform the duty of hearing Mary's confession. The decision may have been taken to reduce the number of active characters in the first place, but has a great symbolic effect.

In the representation of female agency, the confession scene is highly significant. Hanna authoritatively and firmly takes Mary's confession and urges her not to forget anything. The fact that Mary entrusts her with the task of blindfolding her on the way to the scaffold, confirms the image of woman as a caring, motherly force both at the beginning and end of life. That precisely this womanly role is complemented with the care for the soul, a role that has been categorically entrusted in European culture to the patriarchal force of the Church, is a highly significant representation of female authority restored. In this scene of striking beauty, women are revealed as having no need for patriarchal authority in order to come to terms with themselves. The scene may have offered a telling reversal of the one in Boris Godunov Van Hove chose not to set: the power exchange between the Jesuit and the would-be autonomous woman, who in the end turned out to be incapable of liberating herself from patriarchal bonds in matters of the soul.

The advancement of the original Boris Godunov on the international stage enriches the repertoire. Great productions reveal its qualities and demonstrate its viability as a text in its own right. That it offers food for critical thought is also a positive sign of the great work's continuing relevance. Boris Godunov reveals itself all the more as a cluster of 
textural, historical and political concerns. As a product of Russia's age of realism, the opera continues to stimulate thought on history and how it could be represented in art. Questions about the representation of modern societal values, in general, and of feminine agency in particular should not hinder performances of the 1869 version, but are unavoidable in the dialogue between an historical text and the world we live in. In Van Hove's production, the omission of female agency reduces the concept of the political to the confines of a patriarchal past that is not only out of tune with modern societal standards, but proves to be historically inaccurate as well.

Today, feminist criticism insists on the relationship between the fictional representations and the world that we actively construct. In the context of contemporary popular culture, Aisha Harris commented upon the film industry's choice of plots without women or people of color based on the assumption of historical veracity:

"Not unlike our school textbooks, the movie industry cherry-picks from 'history.' Certainly filmmakers should have the artistic freedom to make a movie about white men racing cars or white men in crime organizations. But let's not pretend that this isn't also a choice - a choice dictated not by the past, but by an erroneous (and perhaps unconscious) belief that white men have done the most and lived the most interesting lives of us all." 49

Is the situation in opera that different, just because it has the aura of high art? Surely, the genre could never match the impact of a mass medium. The culture of opera entails a greater weight on the aesthetic in its own right. Nevertheless, both opera producers and audiences repeatedly refer to the continuing relevance of the repertoire as a means to reflect on contemporary issues. 
Nineteenth-century opera has rightly been criticized for its representation of women within the confinements of patriarchal structures and prescribed gender roles. However, most of those characters often display at least a will of their own. Verdi's Violetta does not simply give in to the threats of the bourgeois father figure, but struggles with her own conscience and her inner doubts about her right to redemptive love. Rigoletto's tragedy is not only inflicted upon him by the criminal conduct of the Duke and a hired assassin, but also through his daughter Gilda's rebellion against her father's imposition of his distorted vision on the world. Likewise, Marina Mniszech would offer much potential for responsible stage directors.

One conclusion looms large: if we want theater to represent contemporary societal values - or at least develop a dialogue with them - we must really want it and take action to implement our political commitment. Ivo van Hove demonstrated as much in his production of West Side Story for Broadway, in which the impulse to update the political relevance of the iconic American musical was present from the beginning of his involvement in the project. For Boris Godunov, he made another choice. An artist has every right to let aesthetic values prevail over societal ones. But it remains hard to accept that in such important contemporary concerns as women's rights, even at the height of the \#MeToo moment, a nineteenth-century artist proves to have been ahead of us. 


\section{Acknowledgments}

My sincere thanks to Aleksei Yudin of Ghent University and Charlotte Gruber for suggestions and corrections, and to Simon Hatab, Marion Mirande of the Paris Opéra and to Marlene Kenens of Internationaal Theater Amsterdam for providing me with video registrations. I also thank Jan Vandenhouwe, Ivo van Hove's dramaturge for Boris Godunov and now artistic director of Opera Ballet Vlaanderen for providing valuable first-hand information on the production process.

1 “Lorsque Stéphane Lissner m'a proposé de mettre en scène Boris Godounov, j'ai accepté en précisant effectivement que je souhatais - en accord avec Vladimir Jurowski - monter la version originale."

Simon Hatab, "Vox Populi: Entretien avec Ivo van Hove et Jan Vandenhouwe," in Modeste Moussorgski: Boris Godounov (Paris: Opéra National de Paris), 32.

2 Caryl Emerson and William Oldani, Modest Musorgsky and Boris Godunov: Myths, Realities, Reconsiderations (Cambridge: Cambridge University Press, 1994), 286.

3 Performance available on YouTube: https://www.youtube.com/watch? v=16NiqpBZMpM

4 Performance available on Youtube: https://www.youtube.com/watch?v=GYvC-e2eb5s

5 "Dans l'opéra de Moussorgsky, Boris a une vision. Il propose des solutions concretes. Mais il commet une erreur en croyant pouvoir gouverner depuis son bureau au Kremlin. D’où sa rupture avec le people." Simon Hatab, "Vox Populi," 34.

6 “Elle ne comporte pas l'acte polonais, pas de ballet, pas d'histoire d'amour. Les rôles secondaires y sont réduits à quelques répliques éparses. En se concentrant sur l'ascension et la chute du tsar Boris, cette version est plus shakespearienne." Simon Hatab, "Vox Populi," 32.

${ }^{7}$ Emerson and Oldani, Modest Musorgsky and Boris Godunov, 134-142.

8 "Je crois que c'est la version que voulait Moussorgski. Elle me paraît plus personnelle, plus dramatique, plus politique."

Simon Hatab, "Vox Populi," 32. 
9 Two productions at the Monnaie Opera House in Brussels exemplify this choice: Adolf Dresen's production of 1986 and 1988 and Klaus Michael Grüber's of 2006.

10 Richard Taruskin, Musorgsky: Eight Essays and an Epilogue (Princeton: Princeton University Press, 1993), 258-261.

11 Emerson and Oldani, Modest Musorgsky and Boris Godunov, 210-219.

12 Emily Frey, "Boris Godunov and the Terrorist," Journal of the American Musicological Society 70, no. 1 (Spring 2017): 129-169.

${ }^{13}$ Marina Frolova-Walker, "A Ukrainian Tune in Medieval France: Perceptions of Nationalism and Local Color in Russian Opera," 19th-Century Music 35, no.2 (Fall 2011): 122.

14 Frolova-Walker, “A Ukrainian Tune in Medieval France," 125.

15 Catherine Clément, L'Opéra ou la defaite des femmes (Paris: Grasset, 1979), or Catherine Clément, Opera, or the Undoing of Women, transl. Betsy Wing (Minneapolis: University of Minnesota Press, 1988).

16 Frolova-Walker, “A Ukrainian Tune in Medieval France," 122.

17 Jodi Kantor and Megan Twohey, She Said: Breaking the Sexual Harassment Story That Helped Ignite a Movement (New York: Penguin Press, 2019).

18 Susan Faludi, "'She Said' Recounts How Two Times Reporters Broke the Harvey Weinstein Story," review of She Said: Breaking the Sexual Harassment Story That Helped Ignite a Movement, by Jodi Kantor and Megan Twohey, New York Times, September 8, 2019.

19 Madeline Roache, "Russia's Version of \#MeToo Has Struggled to Take Off - Until Now," Time, June 26, 2019, https://time.com/5636107/metoo-russia-womens-rights/

20 Richard Taruskin, Defining Russia Musically: Historical and Hermeneutical Essays (Princeton: Princeton University Press, 1997), 498-510.

${ }^{21}$ Marina Frolova-Walker, “Lady Macbeth of Mtsensk: Bleak Tragedy or Black Comedy?," The Opera Quarterly 25, no. 1-2 (Winter-Spring 2009): 150-156.

22 Taruskin, Musorgsky, 289.

23 Taruskin, Musorgsky, 261.

24 “Si quittant l'époque contemporaine je reviens maintenant à Stendhal, c'est qu'au sortir de ces carnavals où la Femme tour à tour se déguise en mégère, en nymphe, en étoile du matin, en sirène, il est réconfortant d'aborder un homme qui vit parmi des femmes de chair et d'os."

Simone de Beauvoir, Le deuxième sexe I: Les faits et les mythes (Paris: Gallimard, 1949-1976), 376.

25 Susan McClary, Georges Bizet: Carmen (Cambridge: Cambridge University Press, 1992), 140-141. 
${ }^{26}$ According to a testimony by Lyudmila Shestakova, confirmed by Nikolai RimskyKorsakov; see: Emerson, Oldani, Modest Musorgsky and Boris Godunov, 74; Taruskin, Musorgsky, 250.

27 Francis Maes, "Reality Overtakes Myth: Ivo van Hove stages Der Ring des Nibelungen," in Ivo van Hove Onstage, ed. David Willinger (London: Routledge, 2018), 274-293.

28 Isaiah Gruber, Orthodox Russia in Crisis: Church and Nation in the Time of Troubles (Illinois: Northern Illinois University Press, 2012), 75.

${ }^{29}$ Gruber, Orthodox Russia in Crisis, 82-83.

${ }^{30}$ Chester S. L. Dunning, Russia's First Civil War: The Time of Troubles and the Founding of the Romanov Dynasty (Pennsylvania: The Pennsylvania State University Press, 2001).

${ }^{31}$ Gruber, Orthodox Russia in Crisis, 76.

32 Gruber, Orthodox Russia in Crisis, 80.

33 Monika Greenleaf, Pushkin and Romantic Fashion: Fragment, Elegy, Orient, Irony (Stanford: Stanford University Press, 1994), 162.

${ }^{34}$ Greenleaf, Pushkin and Romantic Fashion, 159.

35 Gruber, Orthodox Russia in Crisis, 188.

${ }^{36}$ Aleksei V. Yudin, "Marina Mniszek glazami rossiiskikh istorikov XVIII - nachala XX v," Shagi/Steps: The Journal of the School of Advanced Studies in the Humanities 2, no. 4 (2016): 60-95.

37 Taruskin, Musorgsky, 194-199.

38 Greenleaf, Pushkin and Romantic Fashion,179.

39 Taruskin, Musorgsky, 282-290.

40 For these ideas in context, see: Harro Höpfl, Jesuit Political Thought: The Society of Jesus and the State, c. 1540-1630 (Cambridge: Cambridge University Press, 2004).

${ }^{41}$ Höpfl, Jesuit Political Thought, 85.

42 Aleksandr Pushkin, Polnoe sobranie khudozhestvennykh proizvedenii (Sankt-Peterburg: Folio-Press, 202), 256. My translation.

43 Ivo van Hove guided the singer through the preparation of the role by suggesting her to take Hillary Clinton as a model (according to a personal communication by the performer Anne Mason). For an analysis of Van Hove's Ring des Nibelungen, see: Maes, "Reality Overtakes Myth," 274-293.

${ }^{4}$ David Willinger, "van Hove, Virtuoso," in Ivo van Hove Onstage, ed. David Willinger (London: Routledge, 2018), 82-84. 
45 Esther Kleuver, “Wereldster Binoche valt tegen op toneel," De Telegraaf, April 10, 2015, translated by Charlotte Gruber, in: Charlotte Gruber, "Love is Still Love Even When it Lacks Harmony: Antigone and the Attempt to Humanize Tragedy," in Ivo van Hove Onstage, ed. David Willinger (London: Routledge, 2018), 268.

46 Kate Kellaway, "Juliette Binoche is More Hysteric Than Heroine," The Guardian, March 8, 2015.

47 Charlotte Higgins, "Death Becomes Her: How Juliette Binoche and Ivo van Hove Remade Antigone," The Guardian, February 18, 2015.

48 Gruber, “Love Still is Love," 271.

${ }^{49}$ Aisha Harris, "Stop Blaming History for Your All-White, All-Male Movie," The New York Times, February 6, 2020. 